\title{
ANALISIS PENGARUH SUMBER DAYA MANUSIA, KESADARAN \\ LINGKUNGAN DAN MODAL SOSIAL TERHADAP KINERJA NELAYAN LOBSTER DI KECAMATAN BUNGO MAS KABUPATEN BENGKULU SELATAN
}

\author{
Oktarina Asmara ${ }^{1)}$, Irnad $^{2)}$, Dede Hartono ${ }^{3)}$ \\ 1) Dinas Pertanian Kabupaten Kaur \\ 2) Jurusan Agribisnis Fakultas Pertanian UNIB \\ 3) Program Studi Ilmu Kelautan Fakultas Pertanian UNIB
}

\begin{abstract}
ABSTRAK
Lobster adalah salah satu komoditi yang memiliki nilai jual tinggi begitu pula dengan jumlah permintaan semakin meningkat. Disamping itu kinerja nelayan lobster juga dipengaruhi oleh beberapa faktor, seperti sumber daya yang dimiliki, lingkungan dan modal sosial. Oleh Karena itu tujuan dalam penelitian ini adalah mengetahui pengaruh sumberdaya manusia, kesadaran terhadap lingkungan dan modal sosial terhadap kinerja nelayan lobster. Responden dalam penelitian ini adalah nelayan lobster yang berada di Kecamatan Bungo Mas Kabupaten Bengkulu Selatan dengan dengan jumlah sampel sebanyak 112 responden. Metode analisis data yang digunakan adalah analisis Structural Equation Modeling (SEM) WarpPLS5.0 yang digunakan untuk melihat hubungan kausalar variabel yang diteliti. Hasil yang diperoleh adalah Variabel sumber daya manusia berpengaruh positif terhadap kinerja nelayan lobster di kecamatan Bungo Mas Kabupaten Bengkulu Selatan Pada tingkat signifikansi 95\% dengan nilai P-Value 0.01 dan $\beta=0.20$. Kemudian, Variabel kesadaran lingkungan berpengaruh positif terhadap kinerja nelayan lobster Pada tingkat signifikansi 95\% dengan nilai P-Value 0.01 dan $\beta=0.20$. Terakhir, Variabel modal sosial berpengaruh positif terhadap kinerja nelayan lobster Pada tingkat signifikansi $95 \%$ dengan nilai P-Value 0.01 dan $\beta=0$. Sehingga dapat disimpulkan bahwa semakin baik sumber daya manusia, kesadaran lingkungan dan modal sosial yang dimiliki nelayan maka kinerja nelayan dalam penangkapan lobster pun akan semakin baik.
\end{abstract}

Kata Kunci: Sumber Daya Manusia, Kesadaran Lingkungan, Modal Sosial, Kinerja Nelayan

\section{PENDAHULUAN}

Keberadaan industri perikanan menjadi perhatian dunia internasional. Berkali-kali pertemuan digelar oleh Badan PBB untuk urusan Pangan dan Pertanian, FAO (Food And Agriculture) terkait dunia perikanan ini. FAO juga sudah menetapkan dan meluncurkan 'The State of World Fisheries and Aquaculture (SOFIA)' sebuah laporan dan dokumen terkait perikanan dan budidaya yang menjadi referensi para anggota FAO dalam memenuhi kebutuhan produksi perikanan di dunia. Produksi perikanan tangkap akan menjadi salah satu komoditas makanan yang paling banyak diperdagangkan di dunia dengan lebih dari $50 \%$ nilai ekspor ikan berasal dari negaranegara berkembang. Ini akan menjadi hal penting dalam pemenuhan kebutuhan pangan dan gizi bagi populasi dunia yang akan berjumlah 9,7 miliar penduduk pada tahun 2050. Dari data di SOFIA, produksi perikanan dunia pada tahun 2025 diproyeksikan sebesar 196 juta ton, yang terdiri dari $52 \%$ berasal dari perikanan 
budidaya dan $48 \%$ dari perikanan tangkap. Proyeksi ini meningkat signifikan dari data produksi perikanan pada 2014 yang sebesar 167,2 juta ton, dengan rincian $44 \%$ perikanan budidaya dan $56 \%$ perikanan tangkap. Proyeksi dibuat FAO melalui analisis data-data konsumsi ikan di tahuntahun sebelumnya (Graziano, 2016).

Nelayan di Indonesia terdiri atas nelayan yang menangkap ikan di laut dan di perairan umum seperti danau sungai dan bendungan. Pada tahun 2015 jumlah nelayan yang menangkap ikan di laut (2.255.650 orang) lebih banyak daripada nelayan yang menangkap ikan di perairan umum (496.840). Profesinya mulai sebagai nelayan pemilik kapal dan alat tangkap (juragan) maupun nelayan buruh (anak buah kapal). Usaha perikanan skala kecil menguasai $94,44 \%$ perikanan tangkap di Indonesia. Nelayan skala kecil umumnya menggunakan perahu tanpa motor dan perahu motor tempel dengan ukuran 5 GT. Mereka umumnya hanya beroperasi di perairan pantai. Adapun kontribusi nelayan tradisional sebesar $75 \%$ dan swasta $25 \%$ dalam produksi perikanan tangkap nasional (Apridar dkk, 2016).

Produksi perikanan Propinsi Bengkulu baik perikanan tangkap maupun perikanan budidaya masih di bawah rata-rata produksi perikanan di Pulau Sumatera. Bahkan mengalami penurunan pada 3 tahun terakhir. Masih rendahnya jumlah produksi perikanan di Propinsi Bengkulu mengindikasikan bahwa ada permasalahan dalam kegiatan produksi perikanan di Propinsi Bengkulu. Produksi perikanan Propinsi Bengkulu dalam kurun waktu lima tahun terakhir menempati posisi terendah dalam sumbangannya pada total produksi perikanan di wilayah Sumatera. Kontribusi produksi perikanan Propinsi Bengkulu hanya menyumbang sekitar 19\% dari total produksi perikanan di Pulau Sumatera.

Produksi perikanan laut di Propinsi Bengkulu tersebar di tujuh kabupaten/kota tertinggi berada di Kota Bengkulu.
Sedangkan Kabupaten Rejang Lebong, Lebong dan Kepahiang tidak memiliki produksi perikanan laut, karena wilayah ketiga kabupaten ini tidak berbatasan dengan Samudera Indonesia. Sedangkan produksi budidaya perikanan terbanyak berada di Kabupaten Lebong.

Kegiatan produksi perikanan di Kabupaten Bengkulu Selatan harus terus dikembangkan, karena sumbangan sub sektor ini dalam PDRB sektor pertanian menunjukkan trend yang terus meningkat meskipun belum signifikan. Berdasarkan data BPS Kabupaten Bengkulu Selatan, rata-rata sumbangan subsektor perikanan sebesar $10 \%$ pada sektor pertanian dalam Produk Regional Domestik Bruto (PDRB). Jumlah produksi perikanan di Kabupaten Bengkulu Selatan dalam waktu empat tahun terakhir.

Ikan jenis tuna dan lobster merupakan produk unggulan tangkapan nelayan Kabupaten Bengkulu Selatan. Potensi hasil tangkap ikan tuna dan lobster hanya 6\% dari potensi perikanan tangkap. Nelayan di Kabupaten Bengkulu Selatan terutama perikanan tangkap masih menggunakan peralatan sederhana dan belum menggunakan kapal-kapal besar. Kurangnya peralatan yang mendukung nelayan dalam bekerja terutama dalam menangkap lobster juga berakibat berkurangnya jumlah personel nelayan yang menangkap lobster.

Hal ini lantas menjadi salah satu pemicu rendahnya tingkat produktivitas perikanan laut. Selain itu ditemukan konflik antar pemangku kepentingan yang masih sering terjadi akibat tumpang tindih kepentingan dalam pemanfaatan ruang pesisir. Hal ini disebabkan adanya perbedaan persepsi diantara para pelaku pembangunan (stakeholders) dalam hal pengelolaan kawasan, yaitu pengelolaan kawasan yang berhubungan dengan pengambilan kebijakan menyeluruh terhadap penataan ruang dan pengelolaan kawasan yang berimbang 
(Dinas Perikanan dan Kelautan Kabupaten Bengkulu Selatan, 2016).

Oleh sebab itulah nelayan tidak memikirkan keberlangsungan lingkungan pantai dalam jangka waktu panjang. Hubungan ketergantungan yang terjadi pada masyarakat nelayan ini merupakan bentuk paling sering terjadi di Indonesia. Nelayan seringkali menjadi golongan yang terpinggirkan dan tidak menjadi prioritas pemerintah. Mereka adalah kaum yang terdesak pada keadaan, karena hanya punya kemampuan untuk melaut dan tidak punya pilihan lain dalam bekerja. Buruh nelayan bekerja pada seorang juragan itu agar bisa memenuhi kebutuhan hidupnya sehari-hari. Sistem yang terjadi pada mereka ini ternyata bukan hanya relasi ekonomi saja, akan tetapi ada relasi sosial yang terjadi.

\section{METODE PENELITIAN}

\section{Waktu dan Lokasi Penelitian}

Penelitian ini dilakukan di Kecamatan Bungo Mas Kabupaten Bengkulu Selatan. Hal ini dikarenakan Kecamatan Bungo Mas memiliki nelayan lobster terbanyak di Kabupaten Bengkulu Selatan. Penelitian ini dilakukan pada bulan April-Mei 2018.

\section{Metode Pengumpulan Data}

Penelitian ini metode pengumpulan data yang digunakan adalah penelitian lapangan (field research), yaitu dengan mendapatkan data primer yang diperoleh secara langsung dengan mendatangi lokasi penelitian dengan cara : (1) Observasi dengan mengadakan tinjauan/penelitian langsung terhadap hal-hal yang berhubungan dengan masalah yang diteliti; (2) Kuisioner dengan membuat suatu lembaran pertanyaan yang nantinya dijawab oleh responden (nelayan) mengenai masalah-masalah yang diteliti, meliputi: sumber daya manusia, kesadaran lingkungan dan modal social serta kinerja nelayan perikanan tangkap di Kabupaten
Bengkulu Selatan. (3) Focus Group Discussion (FGD) dengan melakukan diskusi terarah dengan kelompokkelompok kecil responden yang berasal dari kelompok-kelompok nelayan yang ada di Kabupaten Bengkulu Selatan. (4) Studi dokumentasi terhadap tulisan-tulisan dan data-data yang terkait dengan masalah yang akan di teliti.

\section{Jenis dan Sumber Data}

Jenis data utama dalam penelitian ini berupa data primer, yaitu data yang diperoleh langsung dari lapangan (survey). Subyek penelitian ini adalah nelayan di Kabupaten Bengkulu Selatan. Data sekunder yang digunakan dalam penelitian ini merupakan data pendukung. Data sekunder diperoleh dari dinas/intansi terkait. Data sekunder yang digunakan berupa data hasil produksi perikanan di Kabupaten Bengkulu Selatan serta data terkait lainnya dengan penelitian ini, yang bersumber dari BPS Kabupaten Bengkulu Selatan dan Dinas Kelautan dan Perikanan Kabupaten Bengkulu Selatan.

\section{Analisis Data}

Pengolahan data primer yang diperoleh dari para responden penelitian menggunakan SEM (Structural Equation Models) untuk mengetahui hubunganhubungan antar variabel laten. Tentang variabel laten ini, Wijanto (2007:10) menjelaskan :

SEM variabel kunci yang menjadi perhatian adalah variabel laten (Latent Variables) atau konstruk laten. Variabel laten merupkan konsep abstrak, sebagai contoh : perilaku orang, sikap, perasaan dan motivasi. Variabel laten ini hanya dapat diamati secara tidak langsung dan tidak sempurna melalui efeknya pada variabel teramati. 


\section{HASIL DAN PEMBAHASAN}

\section{Status Pendidikan}

Pendidikan nelayan lobster merupakan salah satu faktor yang memepengaruhi pola pikir nelayan dalam menjalankan usahanya. Tingginya tingkat pendidikan yang ditempuh oleh nelayan juga turut akan mempengaruhi dalam menerima inovasi dan teknologi baru yang disebabkan oleh pengembangan dibidang ilmu pengetahuan. Berdasarkan hasil penelitian yang telah dilakukan pada nelayan lobster di Kecamatan Bungo Mas Kabupaten Bengkulu Selatan, paling banyak nelayan menyelesaikan pendidikan pada tingkat pendidikan menengah pertama (SMP).

\section{Umur}

Umur seseorang dapat menggambarkan seberapa besar efektifitas kerja yang dapat mereka lakukan. Biasanya usia yang lebih muda dapat meyelesaikan pekerjan lebih berat dengan intensitas waktu yang lebih singkat. Angkatan kerja digolongkan sebagai tenaga kerja produktif jika berada pada rentang umur 18 tahun sampai >60 tahun (Tohir, 1998).

Rata-rata umur nelayan lobster di Kecamatan Bungo Mas Kabupaten Bengkulu Selata adalah3 9-44 tahun yang menunjukkan bawa rata-rata nelayan lobster didaerah penelitian berada pada rentang umur tenaga kerja produktif. Dimana paling banyak nelayan berada pada rentang umur 39-44 tahun dengan presentase $30.4 \%$ dan paling sedikit sebanyak $7.1 \%$ nelayan lobster berada pada rentang umur 21-26 tahun. Hal tersebut diperkirakan karena usia 21-26 tahun merupakan usia yang masih sangat muda, biasanya pada rentang usia tersebut yang menjadi tujuan utama dalam mendapatkan pekerjaan lebih kepeda sektor jasa.

\section{Pengalaman}

Berdasarkan penelitian yang telah dilakukan di Kecamatan Bungo Mas Kabupaten Bengkulu Selatan menunjukkan bahwa rata-rata pengalaman melaut yang dimiliki oleh nelayan lobster di daerah penelitian adalah 4-5 tahun, dimana riancian pengalaman melaut yang dimiliki nelayan dapat dilihat pada gambar diagram 4.3 dibawah ini.

Hal ini menunjukan pengalaman kerja yang dimiliki oleh nelayan lobster di Kecamatan Bungo Mas Kabupaten Bengkulu Selatan Masih tergolong rendah.

\section{Jumlah Tanggungan}

Nelayan lobster paling banyak memiliki jumlah anggota keluarga 3-4 orang dengan presentase sebesar $34.8 \%$ dan kemudian sebanyak $31.3 \%$ nelayan memiliki anggota keluarga 5-6 orang. Hal ini menunjukkan bahwa tingkat kelahiran pada masyarakat nelayan masih cukup tinggi. Hal ini juga erat kaitannya dengan tingkat pendidikan dan budaya yang dimiliki nelayan, dimana kebanyakan nelayan beranggapan bahwa banyak anak akan mendatangkan banyak rezeki.

\section{Kelestarian}

persentase paling tinggi kesadaran nelayan terhadap kelestarian lobster di daerah pengangkapan adalah tidak sadar dengan presentase sebesar $52.68 \%$ bahkan sebanyak $20.54 \%$ nelayan sangat tidak sadar terhadap kelestarian lobster. Dimana nelayan belum mampu mengendalikan penagkapan lobster pada batas bobot minimum lobster yang dapat diambil. Pada sekarang ini nelayan lobster tidak terlalu mementingkan ukuran lobster yang mereka tangkap, sebab bayak sekali di pasaran ditemui bahwa ukuran lobster yang dijual oleh pedagang masih dalam ukuran yang relatif kecil. Hal tersebut yang menyebabkan kelestarian lobster tidak terjaga. 


\section{Habitat}

Habitat lobster adalah di laut atau air asin yang memiliki terumbu karang. Pemahaman tentang habitat lobster merupakan suatu nilai plus yang dapat dijadikan sebagai pengetahuan sebagai bekal para nelayan untuk menjadikannya sebagai peluang dalam berwira usaha. Salah satunnya adalah budidaya lobster, karena melihat bahwa pada sekarang ini sudah bermunculan peraturan-peraturan yang berkaitan dengan kelestarian lobster itu sendiri. Sehingga tentunya akan mempengaruhi produksi nelayan dalam melakukan penangkapan lobster di laut.

\section{Periode Penangkapan}

Periode penangkapan lobster yang dilakukan oleh nelayan adalah 8 kali dalam satu bulan dan dapat mencapai 2 kali dalam seminggu jika berada pada masa produktif. Hal tersebut cukup menunjukkan kesadaran nelayan tentang pentingnya periode penangkapan lobster, dimana hal tersebut juga didukung oleh data di atas yang menyebutkan bahwa presentase paling tinggi kesadaan nelayan terhadap periode penangkapan adalah berada pada periode cukup sadar dengan presentase sebesar $31.39 \%$.

\footnotetext{
Alat Tangkap

Alat tangkap juga menjadi salah satu faktor penyebab rusaknya kelestarian habitat lobster jika penangkapan tidak menggunakan alat yang ramah lingkungan.Seperti beberapa kasus yang terjadi di ranah perikanan Indonesia, dimana alat tangkap menjadi isu utama kelestraian ikan di perairan Indonesia. Di Indonesia sendiri sudah banyak jenis alat tangkap yang dilarang beroprasi oleh kementrian kelautan karena dampak negatifnya terhadap kelestarian biota laut maupun terubu karang yang ada di lautan. Contoh alat tangkap yang sudah dilarang kementrian kelautan dan perikanan salah satunya adalah trawl dan pukat harimau. Berdasarkan data penelitian, diperoleh hasil kesadaran
}

nelayan terhadap alat tanggkap yang digunakan dalam menangkap lobster.

\section{Perilaku Konsumsi}

Kesadaran lingkungan yang dimiliki akan membawa konsumen untuk membenahi pola konsumsinya terhadap lobster. Meskipun selama ini lobster dikenal sebagai salah satu produk pangan yang memiliki nilai jual tinggi, namun sama sekali tidak mempengaruhi permintan konsumen. Biasanya lobster menjadi salah satu makanan yang digemari oleh masyarakat dengan pendapatan menengah keatas. Disinilah dibutuhkan kesadaran para nelayan pada kelestarian lobster, karena dengan jumlah permintaan yang tidak sedikit maka nelayan akan rela untuk menagkap lobster yang belum termasuk kedalam kriteria yang dapat ditangkap.

Dimana paling banyak nelayan hanya cukup sadar terhadap pola konsumsi tersebut yaitu sebanyak 31.39\%. Kemudian presentase yang tinggi juga ditunjukkan pada kategori tidak sadar dan sangat tidak sadar dengan masing masing presentase sebesar $31.25 \%$.

\section{Kepercayaan terhadap rekan kerja}

Terkadang kepercayaan antar sesama rekan kerja sangat dibutuhkan dalam modal sosial. Dimana dapat diketahui bahwa modal sosial adalah juga termasuk sumber modal bagi suatu usaha yang juga berpengaruh terhadap faktor produksi.

Serta presentase paling rendah yaitu $0 \%$ pada kategori sangat rendah. Hal ini membuktikan tingkat kepercayan antar sesama nelayan adalah baik, dimana nelayan akan saling membantu dalam menghadapi kesulitan dalam kehidupan sebagai nelayan. Selain itu sebagian besar nelayan juga yakin dan percaya jika teman satu profesinya akan membantu dirinya jika ia mengalami kesulitan di bidang keuangan. Nelayan juga berpendapat akan melakaukan hal sama jika rekan kerjannya membutuhkan pertolongan maka ia juga akan siap mambantunya. 


\section{Norma sosial}

Norma sosial adalah kebiasaan umum yang menjadi acuan prilaku dalam suatu kelompok masyarakat. Norma sosial akan berkembang sesuai degan kesepakatankesepakatan sosial masyarakatnya atau yang sering juga disebut dengan peraturan sosial. Keberadaan norma dalam masyarakat memaksa seorang individu atau kelompok agar bertindak sesuai dengan aturan sosial yang telah ditetapkan atau terbentuk. Pada hakikatnya norma disusun agar hubungan individu dalam kehidupan bermasyarakat dapat berlangsung tertib.

Kemudian pada modal sosial indicator norma social, mayarakat nelayan yang berada pada kategori tinggi dengan presentase $43.80 \%$ dan hanya $2.70 \%$ saja yang memiliki norma sosial dalam kategori sangat rendah. Hal ini membuktikan bahwa norma sosial di masyarakat nelayan lobster adalah baik, dimana kesalah pahaman yang terjadi antar nelayan dapat diselesaikan secara aturan adat yang ada, nelayan juga masih patuh dan ikut dengan aturan-aturan adat yang ada.

\section{Hubungan timbal balik (mutual reciprocity)}

Hubungan muatual reciprocity merupakan hubunggan timbal balik antar individu atau kelompok yang sama-sama memberikan manfaat bagi masing-masing pihak.

Sebelumnya telah dijelaskan mengenai tingkat norma sosial nelayan berada pada kategori baik, begitu pula dengan hubungan mutual reciprocity presentase paling tinggi berada pada kategori yang baik yaitu sebanyak $45.40 \%$.

\section{Jaringan social}

Pada jaringan sosial presentase paling tinggi berada pada kategori cukup tinggi yaitu sebesar $60.70 \%$ bahkan hanya $0 \%$ nelayan dengan tingkat jaringan sosial yang sangat rendah. Hal ini membuktikan bahwa hubungan kerja antar sesama nelayan cukup kuat karena sebanyak $17.90 \%$ nelayan memiliki jaringan sosial yang tinggi bahkan sebanyak $8.90 \%$ nelayan memiliki jaringan sosial yang sangat tinggi. Meskipun demikian, terdapat juga nelayan yang meiliki tingkat jaringan sosial pada kategori rendah walau hanya dengan jumlah yang relative kecil yaitu $2.50 \%$.

\section{Partisipasi nelayan dalam kegiatan kelompok}

Terakhir adalah partisipasi nelayan dalam kegiatan kelompok yang presentase tertingginya berada pada kategori cukup tinggi yaitu sebanyak $50 \%$ dari seluruh nelayan yang ada. Dimana tingkat kehadiran nelayan pada kegiatan yang diadakan oleh organisasi yang ikuti sudah cukup baik, pertemuan dengan anggota kelompok nelayan pun sering diadakan.

\section{Kinerja Nelayan Lobster}

Dalam suatu usaha biaya dapat digolongkan menjadi biaya variabel dan biaya tetap. Pada penelitian ini biaya variabel ialah biaya operasional yang dikeluarkan oleh nelayan per tripnya yang menyangkut tentang penggunaan bahan bakar minyak (BBM), konsumsi, rokok. Biaya tetap dalam penelitian ini ialah biaya yang dikeluarkan nelayan sekali dalam periode tertentu misalnya per bulan ataupun per tahun.

Biaya tetap merupakan biaya paling tinggi yang dikeluarkan oleh nelayan dalam satu kali trip penangkapan lobster yaitu 46,60\% dengan jumlah rupiah sebesar Rp. 107.367 yaitu biaya penyusutan, yang terdiri dari biaya penyusustan kapal, alat tangkap dan mesin. Sedangkan biaya penyusutan yang dikeluarkan oleh nelayan tergantung pada umur ekonomis alat-alat yang dapat digunakan oleh nelayan. Biaya perawatan tergantung pada seberapa rusak alat-alat investasi nelayan, jika semakin sering 
nelayan melakukan perawatan terhadap alat-alat yang dimiliki maka biaya perawatan yang dikeluarkan akan semakin besar. Semakin sering nelayan melakukan perawatan maka kondisi alat investasi akan semakin baik dan dapat digunakan dalam jangka waktu yang lebih lama serta biaya penyusutan yang dikeluarkan oleh nelayan akan semakin kecil.
Perhitungan R/C Ratio digunakan untuk mengetahui efisiensi usaha penangkapan lobster oleh nelayan. Dengan menggunakan analis tersebut dapat diketahui apakah usaha penangkapan lobster yang dilakukan oleh nelayan efisien atau tidak diusahakan. Berikut detail efisiensi usaha penangkapan lobster yang disajikan pada Tabel 1.

\section{R/C Ratio}

Tabel 1. Efisiensi Usaha Penangkapan Lobster

\begin{tabular}{lll}
\hline \multicolumn{1}{c}{ Uraian } & Nilai (Rp/Trip) \\
\hline Penerimaan (TR) & 673.571 & \\
Total Biaya (TC) & 230.459 & \\
\hline R/C Ratio (TR/TC) & & 3.1 \\
\hline
\end{tabular}

Berdasarkan Tabel 1 dapat diketahui bahwa R/C Ratio memiliki nilai 3.1. Dimana nilai tersebut dapat menjelaskan bahwa usaha penangkapan lobster yang dilakukan nelayan dapat dikatakan efisien karena R/C Ratio memiliki nilai >1.

\section{ROI (Retrun Of Investmen)}

Perhitungan nilai ROI dilakukan untuk mengetahui kemampuan menghasilkan laba dari aktiva yang digunakan untuk setiap trip penangkapan lobster yang dilakukan oleh nelayan (Tabel 2).

Tabel 2. ROI (Retrun Of Investmen) Usaha Penangkapan Lobster

\begin{tabular}{lll}
\hline & \multicolumn{1}{c}{ Uraian } & \multicolumn{1}{c}{ Nilai (Rp/Trip) } \\
\hline Pendapatan $(\pi)$ & & 443.113 \\
Investasi & ROI \% ( $\pi /$ Investasi x 100) & 25.733 .036 \\
\hline \multicolumn{2}{c}{$1.9 \%$} \\
\hline
\end{tabular}

Nilai ROI diperoleh dari perbandingan antara nilai pendapatan dan nilai investasi dikali seratus persen. Dengan menggunakan analis tersebut dapat diketahui apakah usaha penangkapan lobster yang dilakukan oleh nelayan efisien atau tidak diusahakan. Berdasarkan tabel R/C Ratio memiliki nilai 1.9. Dimana nilai tersebut dapat menjelaskan bahwa setiap satu trip penagkapan lobster nelayan dapat mengembalikan biaya investasi sebesar $1.9 \%$.

\section{Analisis Structural Equation Model (SEM)}

Analisis structural equation modeling ini dilakukan untuk mengetahui hubunga antar variabel yang diteliti yaitu pengaruh variabel sumber daya manusia, kesadaran lingkungan dan modal sosial terhadap kinerja nelayan lobster.Variabel-variabel tersebut telah dijabarkan pada subbab sebelumnya sehingga diperoleh indikatorindikator yang digunakan dalam analisis ini. Pada penelitian ini, analisis data akan diolah menggunakan SEM-PLS melalui aplikasi WarpPLS 5.0. Didalam PLS terdapat dua langkah pegujian model yang harus dilakukan yaitu pengujian Outer model atau mengukur measurement mod- 
elnya serta pengujian Inner model atau mengukur model strukturalnya.

Hasil output, menjelaskan bahwa APC memiliki indeks sebesar 0.203 dengan nilai $p$-value 0.006. Berdasarkan kriteria, APC sudah memenuhi kriteria karena memiliki nilai $\mathrm{p}<0.005$. Begitu pula dengan nilai $p$-value dari ARS yaitu $p$ $0.037<0.05$. Nilai AVIF yang harus $<3.3$ sudah terpenuhi karena berdasarkan data tersebut AVIF nilainya 1.058. Dengan demikian maka inner model dapat diterima.

\section{KESIMPULAN DAN SARAN}

Berdasarkan hasil dan pembahasan yang telah dilakukan maka dapat disimpulkan bahwa Variabel sumber daya manusia berpengaruh positif terhadap kinerja nelayan lobster di Kecamatan Bungo Mas Kabupaten Bengkulu Selatan. Berarti bahwa semakin baik sumberdaya manusia yang dimiliki nelayan maka kinerja nelayan pun akan semakin baik.

Variabel kesadaran lingkungan berpengaruh positif terhadap kinerja nelayan lobster di Kecamatan Bungo Mas Kabupaten Bengkulu Selatan. Berarti bahwa semakin baik kesadaran lingkungan yang dimilik inelayan maka kinerja nelayan pun akan semakin baik.

Variabel modal sosial berpengaruh positif terhadap kinerja nelayan lobster di Kecamatan Bungo Mas Kabupaten Bengkulu Selatan. Berarti bahwa semakin baik modal sosial yang dimiliki nelayan maka kinerja nelayan pun akan semakin baik.

\section{DAFTAR PUSTAKA}

$\begin{array}{crr}\text { Anonim. } 2010 . & \text { Asistensi } & \text { Fasilitas } \\ \text { Pemberdayaan } & \text { Tenaga } & \text { Kerja }\end{array}$

Pengolahan dan Pemasaran di Provinsi Kalimantan Timur. Makalah Direktorat Usaha dan Investasi Ditjen P2HP.

Arikunto S. 1998. Prosedur Penelitian. Jakarta: Rineka Cipta.

Bamba dan Novalina. 2008. Faktor-faktor yang Mempengaruhi Hasil Tangkapan Nelayan Tradisional di Desa Paranggi Kecamatan Ampibabo Kabupaten Parigi Moutong. J. Agribisnis 9 (3): 168-175. Desember 2008. ISSN 1412-3657. Fakultas Pertanian Universitas Palu.

Daniel M. 2002. Pengantar Ekonomi Pertanian. Jakarta: Penerbit Bumi Aksara.

Daryanto A. 2010. Minapolitan: Strategi Peningkatan Daya Saing Perikanan Berbasis Klaster. http://www.mb.ipb.ac.id/artikel/...

Kementrian Kelautan dan Perikanan. Pedoman Pengelolaan Pelabuhan Perikanan, Direktorat Jenderal Perikanan Tangkap, Jakarta.

Purwanti. 2010. Model Ekonomi Nelayan Rumah Tangga Sekala Kecil. Malang: Universitas Brawijaya Press.

Rasdani M 2004. Petunjuk Teknis Identifikasi Sarana Perikanan Tangkap Jaring Insang (Gill Net). Semarang: Balai Pengembangan Penangkapan Ikan,.

Riduwan, 2008. Pengukuran Variabelvariabel Penelitian. Jakarta.

Sumantri S. 2005. Faktor-faktor yang Mempengaruhi Penangkapan ikan Laut periode 1976-2003. Tesis. Magiater Perencanaan dan Kebijakan Publik FE Universitas Indonesia. http://eprints.lib.ui.ac.id/1201/1/10837 1 ...pdf 